\title{
SIFAT FISIK DAN MEKANIK PAPAN PARTIKEL AMPAS DAN SERAT KULIT BATANG SAGU (Metroxylon spp) BERDASARKAN KOMPOSISI SUSUNAN PARTIKEL DAN RASIO PEREKAT ASAM SITRAT SUKROSA
}

\author{
(Physical and mechanical properties of particleboard from dregs and sago stem bark fibers \\ (Metroxylon spp) based on the composition of the particles and adhesive ratio of citrid acid-sucrose)

\section{Trisnawati, Dina Setyawati, Nurhaida} \\ Program Studi Ilmu Kehutanan Fakultas Kehutanan Universitas Tanjungpura Pontianak \\ Jl. Daya Nasional, Pontianak 78124 \\ E-mail : ttrisnatris28@gmail.com
}

\begin{abstract}
The purpose of this study is to analyze the effect of layer composition and the ratio of citric acid-sucrose as well as the interaction of both of them to the optimum quality of the particleboards. Particleboards were made in sizes $30 \mathrm{~cm} \times 30 \mathrm{~cm} \times 1 \mathrm{~cm}$ with a target density of $0.7 \mathrm{gr} / \mathrm{cm} 3$. Particleboards were prepared by hot pressing at temperature of $160{ }^{\circ} \mathrm{C}$ for 20 minutes with a pressure of $25 \mathrm{~kg} / \mathrm{cm}^{2}$. Particleboards consists of 3 layers with a composition of layers, namely f/b70: c30, flb60: c40, and f/b50: c50, with a surface layer (face, back) made form of sago stem bark and core layers made form of pulp sago. Ratio of citric acid-sucrose in this study was varied from 0/100, 25/75, 75/25, and 100/0. Particleboards testing refers to standard JIS A 5908-2003 Type 8. The results showed that the layer composition had a significant effect on density, water absorption, internal bond (IB), and screw holding strenght. Meanwhile ratio of citrid acid-sucrose significantly affected the water content, water absorption, thickness development, MOE, MOR, internal bond (IB), and screw holding strenght. The interaction beetwen the composition layer factor and ratio of citrid acid-sucrose has a significant effect on water content, thickness development, MOE, MOR, and internal bond (IB). The best particleboards is in the treatment with the composition of the layer f/b70: c30 and the ratio of citric acid-sucrose 25/75 with a density value of $0.7675 \mathrm{gr} / \mathrm{cm} 3$, a moisture content of $7.5939 \%$, modulus of rupture (MOR) $161.4350 \mathrm{~kg} / \mathrm{cm} 2$, and the screw holding strength is $66.1930 \mathrm{~kg} / \mathrm{cm} 2$.
\end{abstract}

Keyword: citrid acid-sucrose, composition of layers, dregs and fibers of sago, particleboards

\section{Abstrak}

Tujuan dari penelitian ini adalah untuk menganalisa pengaruh komposisi lapisan dan perbandingan asam sitrat-sukrosa serta interaksi keduanya terhadap kualitas papan partikel yang optimum. Papan partkel dibuat dengan ukuran $30 \mathrm{~cm} \times 30 \mathrm{~cm} \times 1 \mathrm{~cm}$ dengan target kerapatan 0,7 $\mathrm{gr} / \mathrm{cm}^{3}$. Papan partikel dikempa panas pada suhu $160^{\circ} \mathrm{C}$ selama 20 menit dengan tekanan $25 \mathrm{~kg} / \mathrm{cm}^{2}$. Papan partikel terdiri dari 3 lapisan dengan komposisi lapisan yaitu f/b70 : c30, f/b60: c40, dan f/b50 : c50, dengan lapisan permukaan (face, back) berupa serat kulit batang sagu dan lapisan inti (core) berupa ampas sagu. Rasio asam sitrat-sukrosa dalam penelitian ini bervariasi 0/100, 25/75, 75/25, dan 100/0. Pengujian papan partikel mengacu pada standar JIS A 5908-2003 Type 8. Hasil penelitian menunjukkan faktor komposisi lapisan berpengaruh nyata terhadap kerapatan, daya serap air, keteguhan rekat internal (IB) dan kuat pegang sekrup. Sedangkan faktor rasio perekat asam sitrat sukrosa berpengaruh nyata terhadap kadar air, daya serap air, pengembangan tebal, MOE, MOR, keteguhan rekat internal (IB), dan kuat pegang sekrup. Interaksi antara faktor komposisi lapisan dan rasio asam sitrat-sukrosa berpengaruh nyata terhadap daya serap air, pengembangan tebal, MOE, MOR, dan keteguhan rekat internal (IB). Papan partikel terbaik terdapat pada perlakuan dengan komposisi lapisan flb70 : c30 dan perbandingan asam sitrat-sukrosa 25/75 dengan nilai kerapatan $0,7675 \mathrm{gr} / \mathrm{cm} 3$, kadar air 7,5939\%, keteguhan patah (MOR) 161,4350 kg/cm2, dan kuat pegang sekrup $66,1930 \mathrm{~kg} / \mathrm{cm} 2$.

Kata Kunci : ampas dan serat sagu, asam sitrat-sukrosa, komposisi lapisan, papan partikel 


\section{PENDAHULUAN}

Tanaman sagu (Metroxylon spp) merupakan tanaman asli Indonesia yang dimanfaatkan sebagai sumber pangan dan makanan pokok di beberapa daerah. Data produksi sagu yang dihasilkan pada tahun 2018 diketahui sebanyak 2.147,02 ton (BPS, 2018). Menurut Idral et al. (2012) pada proses produksi sagu dihasilkan tiga jenis limbah, yaitu limbah empelur sagu berserat (ampas sagu), kulit batang sagu (bark) dan air buangan (waste water). Kulit batang sagu umumnya dimanfaatkan oleh masyarakat sebagai lantai pabrik sagu, jalan setapak, jembatan, material dinding, pagar dan kayu bakar. Hasil penelitian Idral et al. (2012) menyatakan kulit batang sagu memiliki komposisi kimia yaitu, selulosa $65,86 \%$, lignin $37,70 \%$, zat ekstraktif $8,31 \%$ dan kadar abu $4,73 \%$. Ampas sagu mengandung residu lignin sebesar 21\%, sedangkan kandungan selulosanya sebesar $20 \%$ dan sisanya merupakan zat ekstraktif dan abu (Kiat 2006 dalam Denitasari 2011). Tingginya kandungan lignoselulosa yang terdapat pada limbah sagu berpotensi sebagai bahan untuk pembuatan papan partikel. Pembuatan papan partikel dari ampas dan serat kulit batang sagu diharapkan dapat menghasilkan produk yang lebih memiliki nilai ekonomi, sehingga limbah dari pengolahan sagu dapat termanfaatkan dengan baik.

$$
\text { Papan partikel merupakan }
$$
produk panel yang dihasilkan dari partikel-partikel kayu dimanfaatkan dan diikat dengan perekat (Bowyer et al.
2003). Kualitas sifat fisik dan mekanik papan partikel biasanya dipengaruhi oleh faktor perekat. Pembuatan papan partikel sebagian besar masih menggunakan perekat sintetis yang mengandung formaldehida yang dapat mengganggu kesehatan dan lingkungan. Menurut Umemura et al. (2011) asam sitrat mempunyai potensi sebagai perekat melalui ikatan kimia dan merupakan salah satu perekat alami yang ramah lingkungan.

Penelitian pemanfaatan ampas sagu sebagai papan partikel dengan perekat alami sudah dilaporkan diantaranya Lestari et al. (2018), Wiwit et al. (2019) dan Wesly et al. (2019), sedangkan penelitian pembuatan papan partikel dari serat kulit batang sagu telah dilaporkan Suhaimi et al. (2018) dan Nugroho et al. (2018). Penelitian papan partikel yang telah dilakukan hanya menggunakan salah satu limbah dari pengolahan sagu, sementara limbah kulit dan ampas sagu yang dihasilkan cukup banyak. Sehingga dilakukan penelitian papan partikel dengan kombinasi antara serat kulit batang sagu dan ampas sagu yag diharapkan dapat meningkatkan kualitas papan partikel dari limbah sagu serta pemanfaatan limbah sagu yang seimbang. Bowyer et al., (2003) menyatakan papan partikel berlapis tiga merupakan papan yang terbuat dari ukuran partikel kayu berbeda antara bagian tengah dan permukaannya. Peningkatan perbandingan antara lapisan permukaan dan lapisan inti (shelling ratio) pada pembuatan papan dapat memperbaiki sifat fisik dan mekanik dari 
papan partikel yang dihasilkan (Nemli et al. 2003). Oleh karena itu, akan dilakukan penelitian mengenai sifat fisik mekanik papan partikel ampas dan serat kulit batang sagu (Metroxylon spp) berdasarkan komposisi susunan lapisan dan rasio perekat asam sitrat-sukrosa. Tujuan dari penelitian ini adalah untuk menganalisa pengaruh komposisi lapisan dan perbandingan asam sitrat-sukrosa serta interaksi keduanya terhadap kualitas papan partikel yang optimum.

\section{METODE PENELITIAN}

Penelitian ini dilaksanakan selama \pm 4 bulan di Laboratorium Pengolahan Kayu dan Laboratorium Wood Workshop Fakultas Kehutanan Universitas Tanjungpura, Laboratorium PT. Duta Pertiwi Nusantara (DPN). Bahan yang digunakan adalah ampas sagu, serat kulit batang sagu dan perekat alami asam sitrat-sukrosa 20\% berdasarkan berat kering partikel. Ampas sagu digunakan dengan ukuran lolos 8 mesh tertahan 10 mesh dan serat

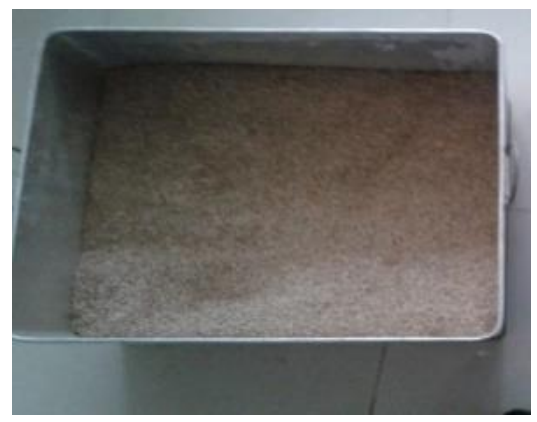

kulit batang sagu dengan panjang $10 \mathrm{~cm}$. Perbandingan asam sitrat-sukrosa dalam penelitian ini bervariasi $0 / 100,25 / 75$, $75 / 25$, dan 100/0. Papan partikel terdiri dari 3 lapisan yaitu face (f), back (b) dan core (c) dengan komposisi lapisan yaitu f/b70 : c30, f/b60 : c40, dan f/b50 : c50, dengan lapisan permukaan (face, back) berupa serat kulit batang sagu dan lapisan inti (core) berupa ampas sagu. Papan partikel dibuat dengan ukuran 30 $\mathrm{cm} \times 30 \mathrm{~cm} \times 1 \mathrm{~cm}$ dengan target kerapatan $0,7 \quad \mathrm{gr} / \mathrm{cm}^{3}$. Proses pengempaan papan partikel dilakukan selama 20 menit pada suhu $160{ }^{\circ} \mathrm{C}$ dengan tekanan $25 \mathrm{~kg} / \mathrm{cm}^{2}$. Pengkondisian papan partikel dilakukan selama satu minggu pada suhu ruang. Pemotongan dan pengujian sifat fisik dan mekanik papan partikel mengacu pada standar JIS A 5908-2003 Type 8. Analisis data penelitian ini menggunakan pola percobaan faktorial dalam Rancangan Acak Lengkap (RAL).

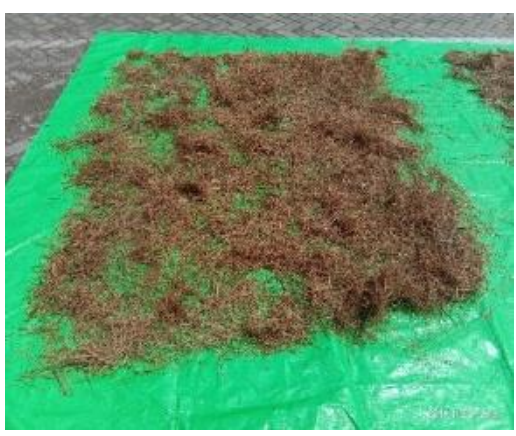

Gambar 1. Ampas dan Serat Kulit Batang Sagu (Dregs and Sago Stem Bark Fibers (Metroxylon spp) 
Tabel 1. Hasil Analisis Keragaman Papan Partikel (The results of the analysis of the diversity of the particle board)

\begin{tabular}{|c|c|c|}
\hline No & Parameter uji & Faktor Perlakuan \\
\hline 1 & Kerapatan & $3,4373^{*}$ \\
\hline 2 & Kadar Air & $17,7756^{* *}$ \\
\hline 3 & Pengembangan Tebal & $6,3925^{* *}$ \\
\hline 4 & Daya serap air & $7,7187^{* *}$ \\
\hline 5 & Modulus Elastisitas & $2,9611^{*}$ \\
\hline 6 & Modulus Patah & $3,8148^{* *}$ \\
\hline 7 & Keteguhan Rekat & $6,7656^{* *}$ \\
\hline 8 & Kuat Pegang Sekrup & $13,3062 * *$ \\
\hline
\end{tabular}

\section{HASIL DAN PEMBAHASAN}

\section{Kerapatan}

Nilai rerata kerapatan papan partkel dari amps dan serat kulit batang sagu menunjukkan bahwa nilai kerapatan sudah mencapai target kerapatan yaitu $0,7 \mathrm{gr} / \mathrm{cm} 3$. Berdasarkan hasil analisis keragaman diketahui bahwa komposisi lapisan berpengaruh nyata terhadap nilai kerapatan papan partikel. Nilai kerapatan papan partikel yang dihasilkan bervariasi, hal ini diduga karena perbedaan bahan baku antara lapisan face yang berupa serat kulit batang sagu dan lapisan core berupa ampas sagu.

Shmulsky dan Jones (2011) berpendapat bahwa kerapatan papan partikel dipengaruhi oleh kerapatan bahan baku, dan bahan tambahan lainnya dalam pembuatan papan partikel. Semakin meningkat komposisi lapisan face dapat meningkatkan nilai kerapatan papan partikel yang dihasilkan. Sejalan dengan penelitian Rofii et al. (2012) menyatakan bahwa semakin tinggi proporsi lapisan face maka kerapatan yang dihasilkan semakin baik. Lapisan face yang berupa serat kulit batang sagu memiliki berat yang lebih tinggi dibandingkan dengan ampas sagu, sehingga papan partikel dengan lapisan face yang tebal akan lebih berat dan menghasilkan nilai kerapatan yang tinggi. Hasil penelitian menunjukkan nilai kerapatan yang dihasilkan telah memenuhi standar JIS A 5908-2003 Type 8 dengan target $0,4-0,9 \mathrm{gr} / \mathrm{cm}^{3}$. Nilai kerapatan papan partikel ampas dan serat kulit batang sagu disajikan pada Gambar 2. 


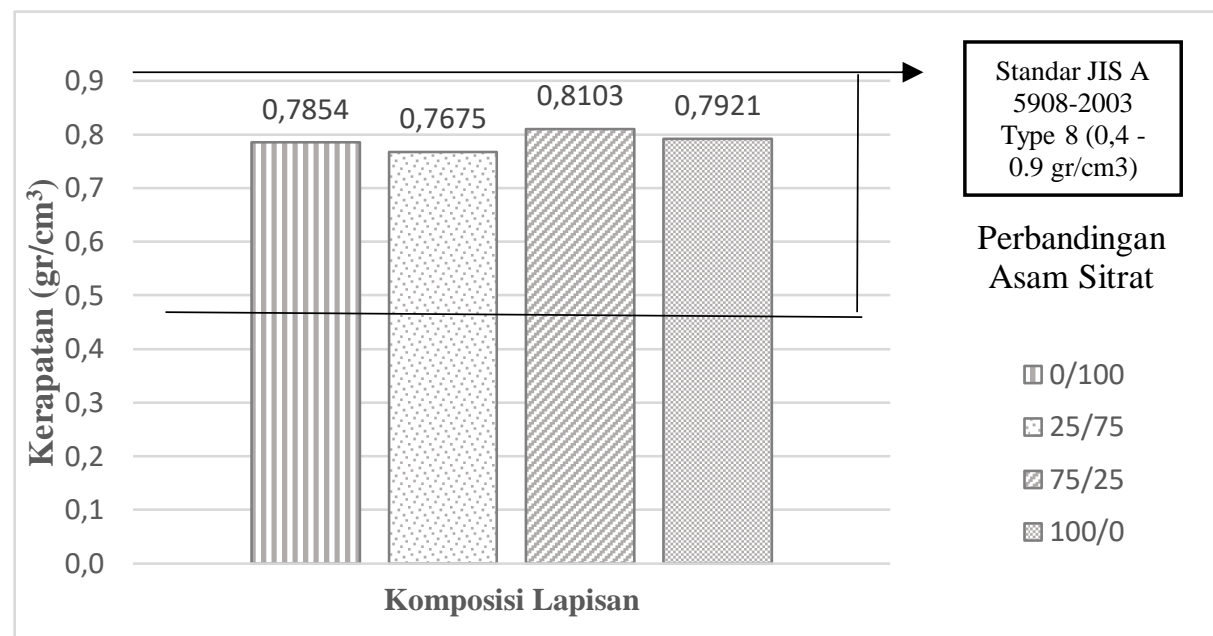

Gambar 2. Nilai Rerata Kerapatan Papan Partikel dari Ampas Dan Serat Kulit Batang Sagu (The average density of particleboard made from dregs and sago stem bark fibers

\section{Kadar Air}

Hasil penelitian menunjukkan nilai rerata kadar air yang dihasilkan sebesar $7,5939 \%$ - 13,3255\%. Hasil analisis keragaman papan partikel menunjukkan bahwa perbandingan asam sitrat-sukrosa berpengaruh sangat nyata terhadap kadar air papan partikel. Kadar air papan partikel dapat dipengaruhi oleh kadar air bahan baku dan persentase penambahan perekat, sesuai dengan pernyataan Bowyer et al. (2003) bahwa perekat serta bahan tambahan lainnya dapat mempengaruhi kandungan air papan partikel.

Secara umum hasil penelitian menunjukkan kombinasi asam sitrat dan surosa dapat menurunkan nilai kadar air papan partikel. Perbandingan rasio asam sitrat sukrosa memiliki nilai kadar air yang lebih rendah dibanding dengan penggunaan asam sitrat $100 \%$. Suhaimi et al. (2018) menyatakan papan partikel dengan perekat asam sitrat memiliki ketahanan perekat yang kurang baik terhadap air. Hal ini disebabkan karena jenis perekat yang berasal dari tumbuhtumbuhan mempunyai daya tahan kelembaban yang sangat rendah serta keutuhan terhadap mikroorganisme masih kurang (Dumanauw 1990, dalam Kusuma 2016) Standar JIS A 5908-2003 Type 8 mensyaratkan nilai kadar air berkisar antara 5\% - 13\%. Nilai kadar air papan partikel disajikan pada Gambar 3. 


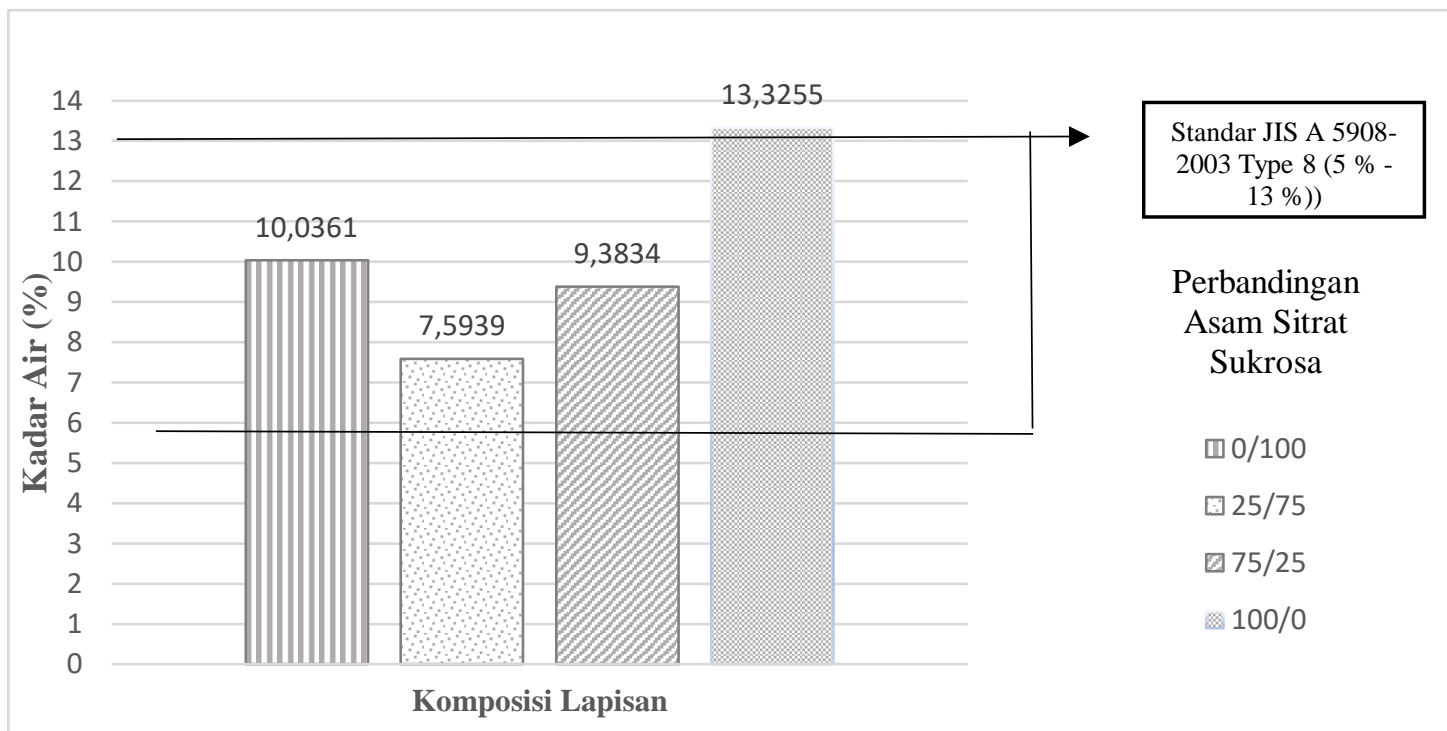

Gambar 3. Nilai Rerata Kadar Air Papan Partikel dari Ampas dan Serat Kulit Batang Sagu (The average moisture content of particleboard made from dregs and sago stem bark fibers)

\section{Daya Serap Air}

Nilai rerata daya serap air papan partikel yang dihasilkan berkisar antara 48,2910\% - 134,8103\%. Hasil analisis keragaman menunjukkan bahwa rasio asam sitrat - sukrosa dan interaksi antar keduanya berpengaruh sangat nyata terhadap daya serap air papan partikel. Standar JIS A 5908 - 2003 type 8 tidak mensyaratkan pengujian terhadap daya serap air, tetapi pengujian daya serap air tetap dilakukan karena berpengaruh terhadap nilai pengembangan tebal. Secara umum papan partikel yang dibuat dengan lapisan face (serat kulit batang sagu) yang lebih tebal memiliki nilai daya serap air lebih tinggi. Hal ini diduga karena sifat bahan baku (serat kulit batang sagu) yang digunakan sebagai lapisan face bersifat higroskopis dan memiliki selulosa yang lebih tinggi daripada ampas sagu, dimana bahan yang mengandung selulosa sangat mudah menyerap dan melepaskan air (Hakim et al. 2011).

Hasil penelitian menunjukkan daya serap air papan partikel yang tertinggi terdapat pada papan partikel dengan perekat $100 \%$ sukrosa. Hal ini disebabkan oleh sifat dasar sukrosa yang merupakan bahan dengan nilai kelarutan dan gugus hidroksil yang cukup tinggi. Hal ini sejalan dengan penelitian Umemura et al. (2012) dimana penggunaan perekat sukrosa $100 \%$ tanpa campuran asam sitrat akan menghasilkan nilai daya serap air yang tinggi. Nilai rerata daya serap air papan patikel disajikan pada Gambar 4. 


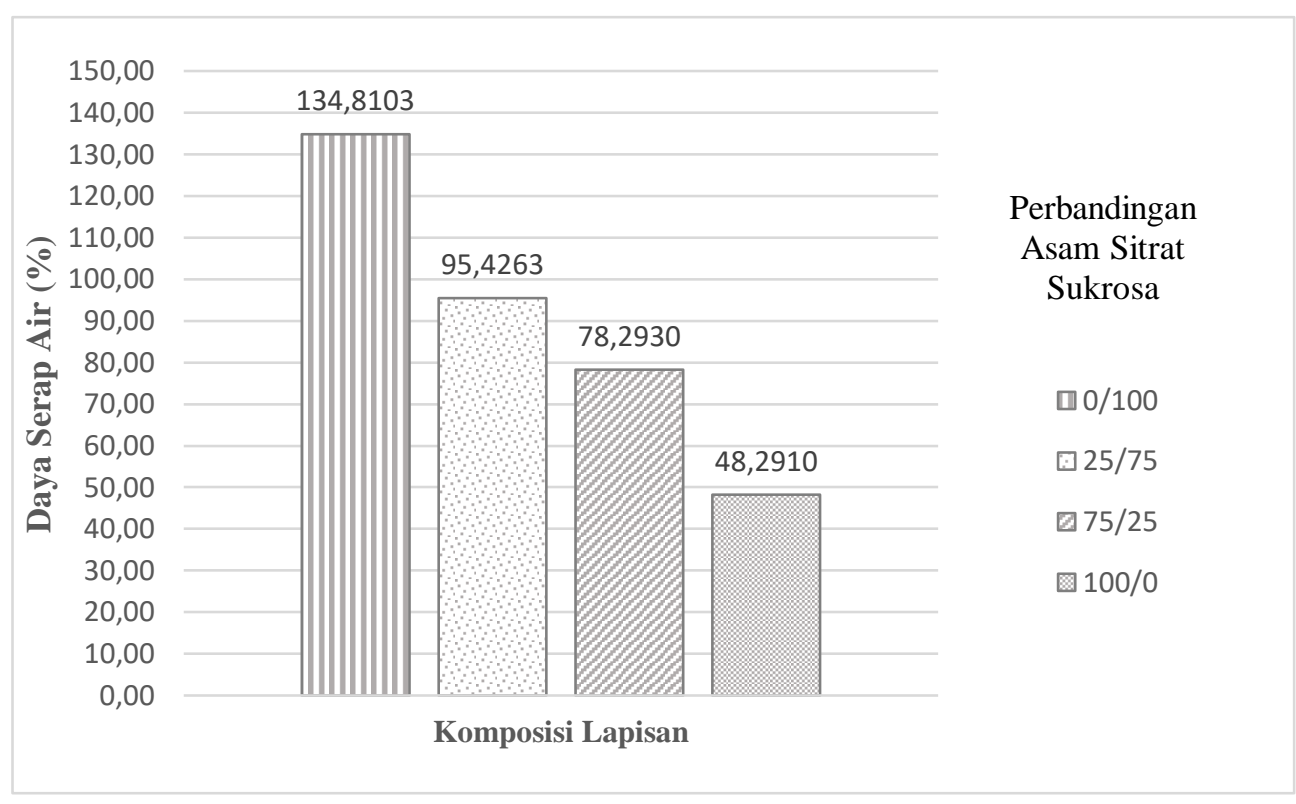

Gambar 4. Nilai Rerata Daya Serap Air Papan Partikel dari Ampas dan Serat Kulit Batang Sagu (The average water absorption of particleboard made from dregs and sago stem bark fibers)

\section{Pengembangan Tebal}

Nilai rerata pengembangan tebal papan partikel yang dihasilkan berkisar antara 20,0924\% - 69,3001\%. Hasil analisis keragaman menunjukkan bahwa interaksi antar rasio asam sitrat-sukrosa dan komposisi lapisan berpengaruh sangat nyata terhadap pengembangan tebal papan partikel. Lapisan permukaan papan partikel yang berupa serat sagu meningkatkan nilai pengembangan tebal. Struktur serat sagu yang kasar mengakibatkan banyaknya rongga sehingga saat dilakukan perendaman selama 24 jam lapisan permukaan papan mengalami pengembangan tebal yang cukup tinggi. Iswanto et al. (2005) dalam Nugroho et al. (2018) mengemukakan bahwa pengembangan tebal berhubungan erat dengan absorsi air, karena semakin banyak air yang diserap papan partikel dan memasuki struktur serat maka semakin besar perubahan dimensi.

Perbandingan rasio asam sitrat sukrosa menghasilkan nilai pengembangan tebal yang lebih rendah dibanding dengan penggunaan sukrosa 100\%. Umemura et al. (2013) menunjukkan bahwa sistem perekatan antara asam sitrat dan sukrosa dapat menghasilkan ikatan yang tahan terhadap air atau kestabilan dimensi yang semakin meningkat. Hasil penelitian menunjukkan nilai pengembangan tebal papan partikel secara keseluruhan belum memenuhi standar JIS A 5908 - 2003 type 8 yang menetapkan standar pengembangan tebal papan partikel yaitu maksimal $12 \%$. Nilai rerata pengembangan tebal papan partikel disajikan pada Gambar 5. 


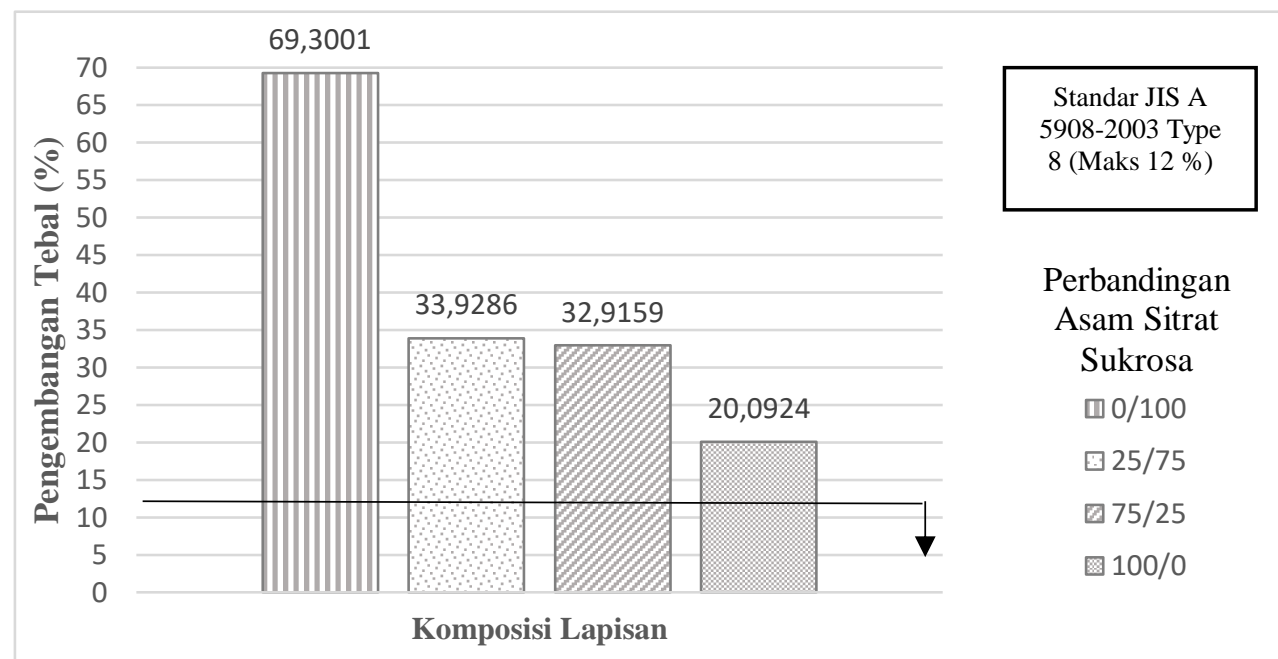

Gambar 5. Nilai Rerata Pengembangan Tebal Papan Partikel dari Ampas dan Serat Kulit Batang Sagu (The average thickness development of particleboard made from dregs and sago stem bark fibers)

\section{Modulus Elastisitas (MOE)}

Secara keseluruhan nilai rerata modulus elastisitas (MOE) papan partikel ampas dan serat kulit batang sagu yang dihasilkan bervariasi. Hasil analisis keragaman menunjukkan bahwa interaksi antar rasio asam sitrat-sukrosa dan komposisi lapisan berpengaruh nyata terhadap modulus elastisitas papan partikel. Modulus elastisitas (MOE) meningkat dengan bertambahnya tebal lapisan face. Ketebalan lapisan face sangat penting dalam pembuatan papan partikel, kenaikan rasio ketebalan lapisan face terhadap ketebalan papan akan meningkatkan sifat fisik dan mekanis papan yang dibuat (Akbulut, 1995 dalam Nemli, 2003).

Papan partikel yang dibuat dengan perekat sukrosa $100 \%$ menghasilkan nilai modulus elastisitas (MOE) yang lebih rendah dibandingkan dengan asam sitrat $100 \%$, hal ini karena asam sitrat memiliki kemampuan mengikat partikel yang lebih kuat dibandingkan sukrosa (Wiwit et al. 2019). Secara umum nilai modulus elastisitas (MOE) terbaik dihasilkan pada papan partikel dengan rasio asam sitrat-sukrosa 25/75. Sejalan dengan penelitian Santoso et al. (2016) dan Wiwit et al. (2019) menyatakan bahwa rasio asam sitratsukrosa (25/75) dapat meningkatkan nilai modulus elastisitas (MOE). Nilai modulus elastisitas (MOE0 papan partikel ampas sagu yang dihasilkan belum memenuhi standar JIS A 59082003 Type 8 yang mensyaratkan nilai modulus elastisitas (MOE) papan partikkel minimum $20400 \mathrm{~kg} / \mathrm{cm}^{2}$. Nilai rerata papan partikel ampas dan serat kulit batang sagu disajikan pada Gambar 6. 


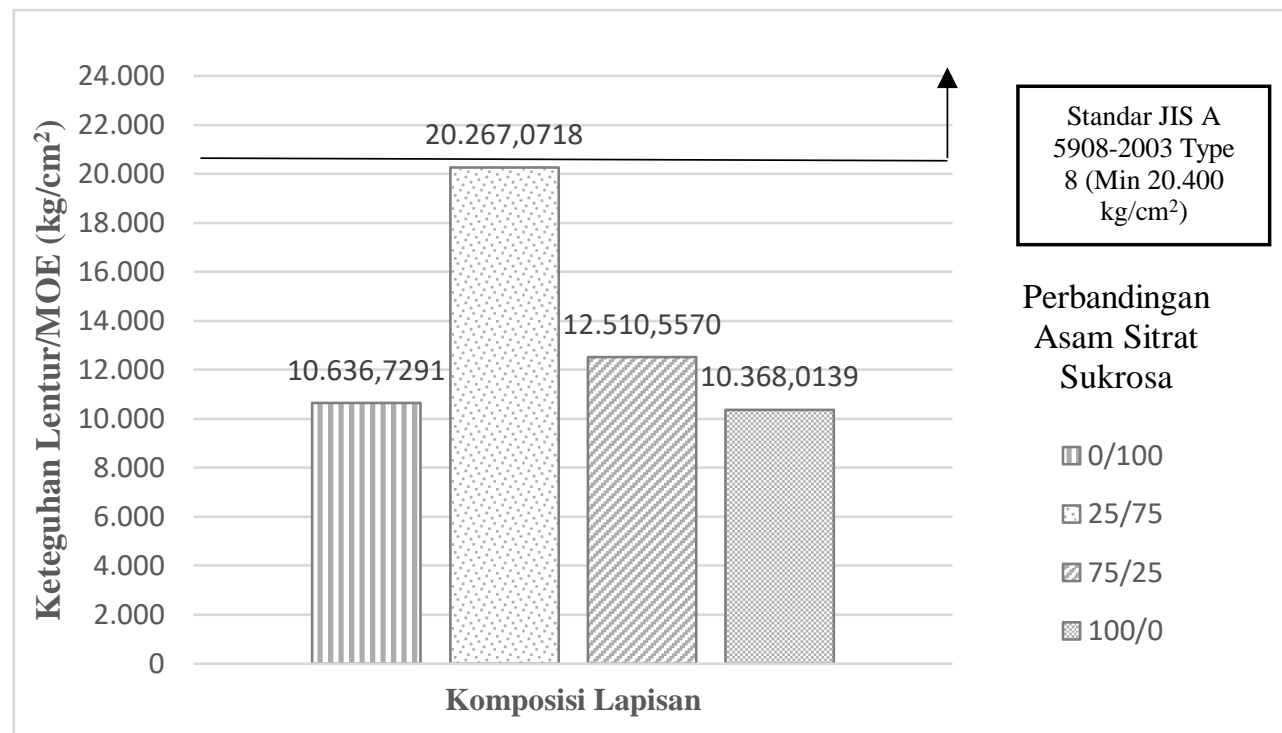

Gambar 6. Nilai Rerata MOE Papan Partikel dari Ampas dan Serat Kulit Batang Sagu (The average MOE of particleboard made from dregs and sago stem bark fibers)

\section{Modulus Patah (MOR)}

Nilai rerata keteguhan patah (MOR) papan partikel ampas dan serat kulit batang sagu berkisar antara 73,2513 $161,4350 \mathrm{~kg} / \mathrm{cm} 2$. Hasil analisis keragaman menunjukkan bahwa interaksi antar rasio asam sitrat-sukrosa dan komposisi lapisan berpengaruh sangat nyata terhadap keteguhan patah (MOR) papan partikel. Berdasarkan komposisi lapisan menunjukkan bahwa nilai keteguhan patah (MOR) terjadi peningkatan seiring dengan berkurangnya komposisi serat kulit batang sagu. Secara umum papan partikel dengan komposisi f/b50:c50 memiliki nilai keteguhan patah yang tinggi. Hal ini diduga karena penggunaan ampas sagu sebagai lapisan core yang lebih tebal sehingga papan partikel yang dihasilkan lebih padat. Sejalan dengan penelitian Wiwit et al. (2019) yang menyatakan ukuran partikel halus akan menghasilkan papan partikel yang lebih padat sehingga menghasilkan nilai MOR yang tinggi.

Hasil penelitian menunjukkan perbandingan rasio asam sitrat-sukrosa dapat meningkatkan keteguhan patah (MOR) papan partikel dibanding dengan penggunaan asam sitrat maupun sukrosa. Lamaming et al. (2013) menyatakan bahwa penambahan sukrosa dapat meningkatkan modulus patah (MOR) papan partkel kelapa sawit. Secara keseluruhan hasil penelitian menunjukkan bahwa tidak semua nilai keteguhan patah (MOR) papan partikel ampas dan serat kulit batang sagu yang dihasilkan memenuhi standar JIS A 5908-2003 Type 8, yang mensyaratkan nilai modulus patah (MOR) papan partikel minimal $82 \mathrm{Kg} / \mathrm{cm}^{2}$. Nilai rerata papan partikel ampas dan serat kulit batang sagu disajikan pada Gambar 7 . 


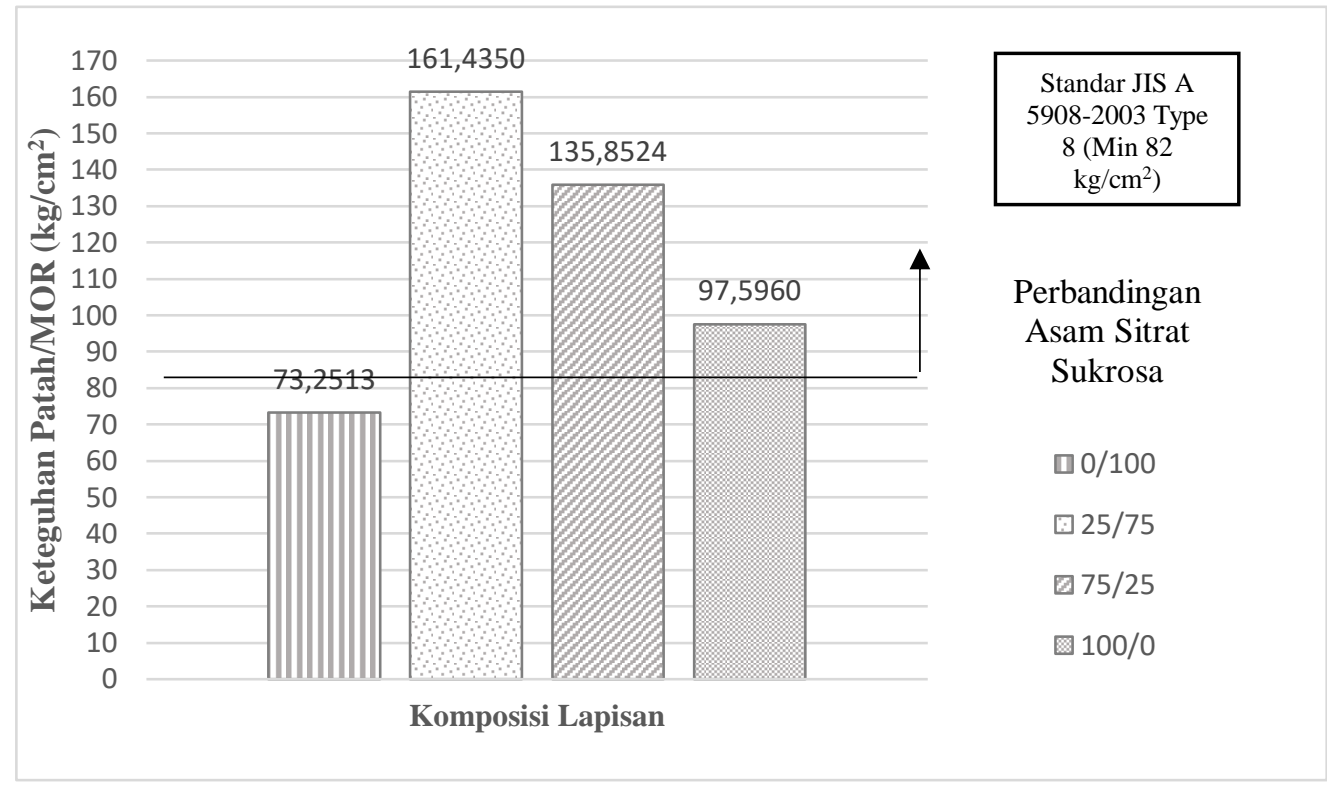

Gambar 7. Nilai Rerata MOR Papan Partikel dari Ampas dan Serat Kulit Batang Sagu (The average MOR of particleboard made from dregs and sago stem bark fibers)

\section{Keteguhan Rekat Internal/IB}

Hasil analisis keragaman menunjukkan bahwa interaksi antar rasio asam sitrat-sukrosa dan komposisi lapisan berpengaruh sangat nyata terhadap keteguhan rekat internal papan partikel. Nilai rerata keteguhan rekat internal papan partikel berkisar antara 0,0869$1,2029 \mathrm{~kg} / \mathrm{cm} 2$ dan belum memenuhi standar JIS A 5908-2003 type 8 yang mensyaratkan nilai keteguhan rekat internal papan partikel minimal 1,5 $\mathrm{kg} / \mathrm{cm}^{2}$.. Rendahnya nilai keteguhan rekat internal papan partikel diduga disebabkan kompatibilitas antara ampas dan serat kulit batang sagu yang rendah akibat perbedaan komposisi kimia antar bahan. Pembuatan papan partikel dengan susunan yang jelas antara serat pada lapisan face dan ampas sagu pada bagian core menyebabkan daya rekat yang rendah antar lapisan furnish sehingga beban tidak dapat ditransfer dengan sempurna pada seluruh lapisan. Mikael et al. (2015) menyatakan semakin seimbang (seragam) komposisi partikel yang digunakan, maka keteguhan rekatnya akan semakin kuat.

Hasil penelitian menunjukkan nilai keteguhan rekat internal akan mengalami peningkatan dengan bertambahnya rasio asam sitrat. Sejalan dengan penelitian Wiwit et al. (2019) yang menyatakan bahwa nilai keteguhan rekat internal meningkat pada rasio asam sitrat-sukrosa (75/25). Widyorini (2011) menyatakan bahwa nilai keteguhan rekat internal papan partikel dipengaruhi oleh jenis partikel dan kadar perekat. Nilai rerata keteguhan rekat internal papan partikel disajikan pada Gambar 8. 


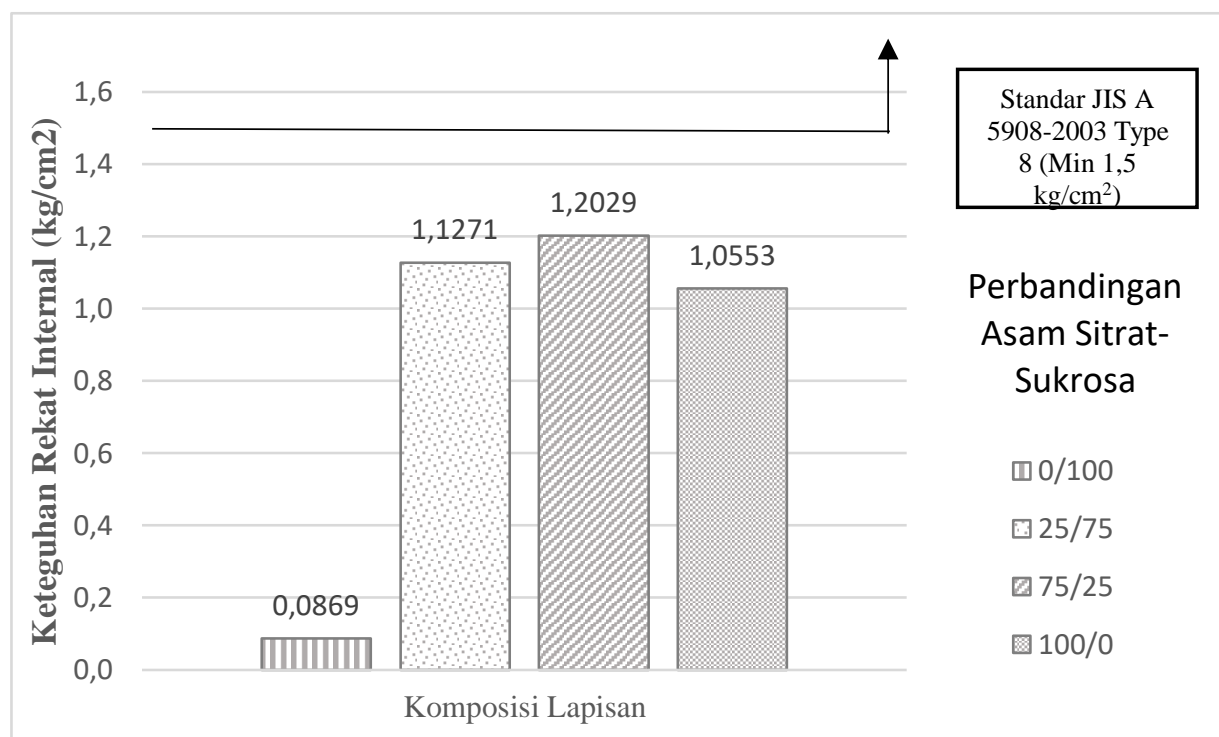

Gambar 8. Nilai Rerata Keteguhan Rekat Internal (IB) Papan Partikel dari Ampas dan Serat Kulit Batang Sagu (The average internal bonding of particleboard made from dregs and sago stem bark fibers)

\section{Kuat Pegang Sekrup}

Hasil penelitian menunjukkan nilai rerata kuat pegang sekrup papan partikel berkisar antara 43,8725- 66,1930 $\mathrm{kg} / \mathrm{cm} 2$. Hasil analisis keragaman menunjukkan rasio asam sitrat - sukrosa berpengaruh sangat nyata terhadap kuat pegang sekrup papan partikel. Secara keseluruhan nilai kuat pegang sekrup papan partikel dengan lapisan face (serat kulit batang sagu) yang tebal menghasilkan nilai yang tinggi dibanding dengan papan partikel dari ampas sagu. Hal ini disebabkan adanya ikatan antar serat yang kuat menjadikan papan partikel lebih kuat, sehingga papan partikel dengan lapisan face yang tebal mudah untuk menahan sekrup. Hal ini sejalan dengan hasil penelitian Handayani et al. (2019) yang menyatakan nilai keteguhan rekat internal papan partikel serat kulit batang sagu telah memenuhi standar JIS A 5908-2003.

Nilai rerata kuat pegang sekrup papan partikel yang dihasilkan sudah memenuhi standar JIS A 5908-2003 type 8 yang mensyaratkan nilai kuat pegang sekrup minimal $31 \mathrm{~kg}$. nilai rerata kuat pegang sekrup papan partikel disajikan pada Gambar 9. 


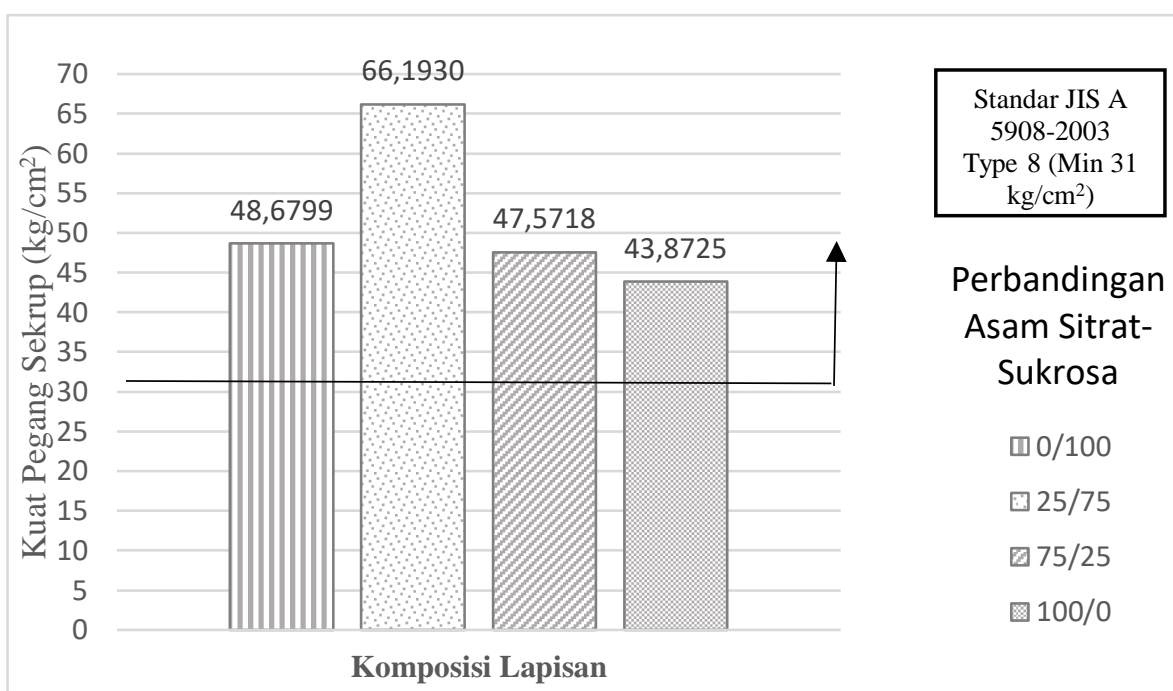

Gambar 9. Nilai Rerata Kuat Pegang Sekrup Papan Partikel dari Ampas dan Serat Kulit Batang Sagu (The average screw holding strength of particleboard made from dregs and sago stem bark fibers)

\section{KESIMPULAN}

Komposisi lapisan berpengaruh nyata terhadap kerapatan, daya serap air, keteguhan rekat internal (IB) dan kuat pegang sekrup, sedangkan rasio perekat asam sitrat sukrosa berpengaruh nyata terhadap kadar air, daya serap air, pengembangan tebal, MOE, MOR, keteguhan rekat internal (IB), dan kuat pegang sekrup. Papan partikel terbaik terdapat pada perlakuan a1b2 (papan partikel dengan komposisi lapisan $\mathrm{f} / \mathrm{b} 70: \mathrm{c} 30$ dan rasio asam sitrat sukrosa 25/75).

\section{SARAN}

1. Perlu adanya pengaturan ukuran partikel yang seimbang antara lapisan face dan core papan partikel tiga lapis.

2. Perlu adanya penelitian lebih lanjut mengenai keawetan papan partikel dari ampas dan serat kulit batang sagu terhadap serangan rayap dan jamur pelapuk kayu.

\section{DAFTAR PUSTAKA}

Bowyer JL, Shmulsky R, Haygreen JG. 2003. Forest Product and Wood Science An Introduction. Fourth Edition. Lowa State Press.

[BPS] Badan Pusat Statistik. 2018. Statistik Produksi Kehutanan 2018. Jakarta. Penerbit Badan Pusat Statistik Indonesia.

Denitasari NA. 2011. Briket Ampas Sagu sebagai Bahan Bakar Alternatif. Departemen Kimia: Fakultas Matematika dan Ilmu Pengetahuan Alam, Institut Pertanian Bogor.

Hakim L, Herawati E, Wistara NJ. 2011. Papan Serat Berkerapatan Sedang Berbahan Baku Sludge Terasetilasi dari Industri Kertas. Jurnal Makara Teknologi 15: 123130.

Handayani GS, Dirhamsyah M, Nurhaida, Setyawati D. 2019. Sifata Fisik dan Mekanik Papan Partikel Serat Kulit Batang Sagu (Metroxylon sago ROTTB.) 
Berdasarkan Ukuran Serat. Jurnal Hutan Lestari. 7(1) : 541-550.

Idral D, Salim M, Mardiah E. 2012. Pembuatan bioetanol dari ampas sagu dengan proses hidrolisis asam dan menggunakan Saccharomyces cerevisiae. Jurnal Kimia UNAND 1(1) : 34-39.

Japan Industrial Standard [JIS]. 2003. Particleboard A 5908. Tokyo: Japanese Standard Association.

Lamaming J, Othman S, Tamoko S, Rokiah H, Norafizah S, Sato $M$. 2013. Influence of chemical components of oil palm on properties of binderless particleboard. J Agric Life Sci. 8(3): 3358-3371.

Lestari M, Setyawati D, Nurhaida. 2018. Karakteristik Papan Partikel dari Ampas Sagu dan Perekat Asam Sitrat Berdasarkan Kerapatan Papan. Jurnal Hutan Lestari 6(3): 428-437.

Maulana S, Purusatama BD, Wistara NJ, Sumardi I, Febrianto F. 2016. Pengaruh Perlakuan Steam pada Strand dan Shelling Ratio Terhadap Sifat Fisis dan Mekanis Oriented Strand Board Bambu. Jurnal Ilmu Teknologi Кауи Tropis 14(2) : 136-143.

Nemli G. 2003. Effects of Some Manufacturing Factors on the Properties of Particleboard Manufactured from Alder (Alnus glutinosa Subs. Barbata). Turk J. Agric. For. 27: 99 - 104.

Nugroho DW, Tavita GE, Setyawati D. 2018. Kualitas Papan Partikel Dari Kulit Batang Sagu (Metroxylon spp) Dengan Perekat Alami Asam Sitrat : Sifat Fisik, Sifat Mekanik dan Keawaetan Terhadap Rayap Tanah Coptotermes curvignathus Holmgren.Jurnal Tengkawang. 8 (2) : $88-101$.

Rofii MN, Widyorini R. 2012. Pengaruh Proporsi Lapisan dan Bahan Baku Terhadap Sifat Papan Partikel Lapis Tanpa Perekat. Seminar Nasional Mapeki XV, Makasar, 67 November 2012. Hlm 141-149.

Suhaimi, Setyawati D, Nurhaida. 2018. Kualitas papan partikel dari serat kulit batang sagu (Metroxylon spp) dengan perekat alami asam sitrat berdasarkan waktu kempa. Jurnal Hutan Lestari 6(3) : 535-547.

Umemura K, Ueda T, Munawar S. S, Kawai S. 2011. Application of citric acid as natural adhesive for wood. Journal of Applied Polymer Science 123: 1991-1996.

Umemura K, Ueda T, Kawai S. 2012. Characterization of wood-based molding bonded with citric acid. Journal wood sci 58: 38-45.

Umemura K, Sugihara O, \& Kawai S. 2013. Investigation of a new natural adhesived composed of citrid acid and sucrose for particleboard. Journal of Wood Science 59, 203-209.

Wesly Y, Dirhamsyah M, Setyawati D, Nurhaida. 2019. Kualitas Papan Partikel dari Ampas Batang Sagu (Metroxylon spp) dengan Perekat Alami Asam Sitrat : Sifat Fisik, Mekanik, dan Keawetan Terhadap Rayap Tanah (Coptotermes curvignathus Holmgren). Jurnal Hutan Lestari. 7(1) : 166-177.

Widyorini R, Prayitno TA, Yudha AP, Setiawan BA, Wicaksono BH. 2012. Pengaruh konsentrasi asam 
sitrat dan suhu pengempaan terhadap kualitas papan partikel dari pelepah Nipah. Universitas Gadjah Mada. Jurnal Ilmu Kehutanan 6(1) : 61-70.

Widyorini R, Yudha AP, Prayitno TA. 2011. Some Of The Properties Of Binderless Particleboard
Manufactured From Bamboo. 2(2).

Wiwit, Setyawati D, Yani A, Nurhaida. 2019. Sifat Fisik Mekanik Papan Partikel dari Ampas Sagu (Metroxylon spp) Berdasarkan Ukuran Partikel dan Perbandingan Asam Sitrat-Sukrosa. Jurnal Hutan Lestari 7(1) : 220-228. 